Check for updates

Cite this: Chem. Sci., 2018, 9, 8134

๑ All publication charges for this article have been paid for by the Royal Society of Chemistry

Received 22nd June 2018

Accepted 23rd August 2018

DOI: $10.1039 / \mathrm{c} 8 \mathrm{sc} 02744 \mathrm{~g}$

rsc.li/chemical-science

\section{A robust iron catalyst for the selective hydrogenation of substituted (iso)quinolones $\uparrow$}

\author{
Basudev Sahoo, (D) a Carsten Kreyenschulte, (D) a Giovanni Agostini, ${ }^{a}$ Henrik Lund, ${ }^{a}$ \\ Stephan Bachmann, ${ }^{\mathrm{b}}$ Michelangelo Scalone, ${ }^{\mathrm{b}}$ Kathrin Junge (D) ${ }^{a}$ \\ and Matthias Beller (D) *a
}

By applying $\mathrm{N}$-doped carbon modified iron-based catalysts, the controlled hydrogenation of $\mathrm{N}$-heteroarenes, especially (iso)quinolones, is achieved. Crucial for activity is the catalyst preparation by pyrolysis of a carbon-impregnated composite, obtained from iron(॥) acetate and $\mathrm{N}$-aryliminopyridines. As demonstrated by TEM, XRD, XPS and Raman spectroscopy, the synthesized material is composed of $\mathrm{Fe}(0), \mathrm{Fe}_{3} \mathrm{C}$ and $\mathrm{FeN}_{x}$ in a $\mathrm{N}$-doped carbon matrix. The decent catalytic activity of this robust and easily recyclable Fe-material allowed for the selective hydrogenation of various (iso)quinoline derivatives, even in the presence of reducible functional groups, such as nitriles, halogens, esters and amides. For a proofof-concept, this nanostructured catalyst was implemented in the multistep synthesis of natural products and pharmaceutical lead compounds as well as modification of photoluminescent materials. As such this methodology constitutes the first heterogeneous iron-catalyzed hydrogenation of substituted (iso) quinolones with synthetic importance.

\section{Introduction}

Fundamentally, the controlled reduction of heteroaromatic compounds to their partially or completely saturated congeners holds long persistent interest in streamlining organic synthesis and in producing fine and bulk chemicals. ${ }^{1}$ As such, molecular hydrogen represents an ideal and clean reducing agent. ${ }^{2}$ Compared to industrially relevant hydrogenations of benzene and related arenes, the reduction of heteroaromatic compounds, especially $\mathrm{N}$-heteroarenes, continues to be a scientific and technical challenge. ${ }^{3-7}$ Achieving the desired selectivity in the hydrogenation of (iso)quinolones as well as the tolerance of coexisting reducible functionalities provides additional problems. Notably, the resulting partial hydrogenation product of quinolines (i.e. 1,2,3,4-tetrahydroquinolines) constitutes a ubiquitous motif in numerous bio-active compounds. ${ }^{8}$ Apart from an array of natural products such as $( \pm)$-galipinine,$^{8 d, e}( \pm)$-cuspareine,$^{8 d, e}$ etc., it is found in agrochemicals and synthetic drugs or lead compounds with distinct pharmaceutical activity, e.g. flumequine, ${ }^{8 f}$ tubulin polymerization inhibitor, ${ }^{8 g}$ histamine- $\mathrm{H}_{3}-$ receptor antagonist, ${ }^{8 h}$ etc. Furthermore, this scaffold is useful in materials science, e.g. photosensitive ${ }^{9}$ and even hydrogen storage ${ }^{4 a, 6 c}$ materials.

${ }^{a}$ Leibniz-Institut für Katalyse e.V. an der Universität Rostock, Albert-Einstein-Str. 29a, 18059 Rostock, Germany.E-mail: matthias.beller@catalysis.de

${ }^{b}$ Process Chemistry and Catalysis, F. Hoffmann-La Roche Ltd., Grenzacherstrasse 124, 4070 Basel, Switzerland

$\dagger$ Electronic supplementary information (ESI) available. See DOI: $10.1039 / \mathrm{c} 8 \mathrm{sc} 02744 \mathrm{~g}$
Over the last decade, implementation of low cost, less toxic and earth-abundant metals represents an attractive alternative to the use of scarce and often toxic precious metals in catalytic hydrogenation technologies. ${ }^{\mathbf{1 0}}$ Despite substantial progress in the hydrogenation of $\mathrm{N}$-heteroarenes by noble metal catalysts (e.g. $\mathrm{Pd}, \mathrm{Ru}, \mathrm{Rh}, \mathrm{Ir}, \mathrm{Au}$, etc.) ${ }^{4,5}$ known homogeneous catalysts sometimes require co-catalysts/additives for substrate or catalyst activation, ${ }^{4}$ while heterogeneous catalysts, sometimes, lack regioselectivity $^{5 h}$ and functional group tolerance. ${ }^{5 f}$ Until recently, selective hydrogenations of $\mathrm{N}$-heteroarenes by base metal catalysts (e.g. Co, $\mathrm{Ni}$, etc.) have been explored to a limited extent. ${ }^{6,7}$ Intriguingly, to chase sustainability and confront environmental concerns, the prime choice of any transition metal in catalysis would be utilizing iron. ${ }^{10 g, 11 a}$ However, it lacks predictability and complete control over its reactivity due to competitive single electron transfer (SET), which requires sophisticated ligand systems in homogeneous catalysis. ${ }^{\mathbf{1 0 1 1}}$

In fact, W. D. Jones and co-workers disclosed that a molecularly defined Fe-PNP pincer complex can promote the hydrogenation of $\mathrm{N}$-heteroarenes in the presence of bases (Fig. 1) ${ }^{6 c}$ In contrast to these sensitive homogeneous systems, operationally simple and robust heterogeneous iron catalysts are not known, except for one example where Shaw et al. demonstrated the hydrogenation of quinaldine at $300{ }^{\circ} \mathrm{C}$ and $5.2 \mathrm{MPa} \mathrm{H}_{2}$ (Fig. 1). ${ }^{12}$

Recently, substantial efforts have been made to provide advanced materials with tunable structure and properties for catalysis in organic synthesis complementary to molecularly well-defined organometallic catalysts..$^{\boldsymbol{a}-\boldsymbol{d}, \mathbf{1 3 - 1 5}}$ In this context, we have developed a spectrum of supported nanostructured metal/ 


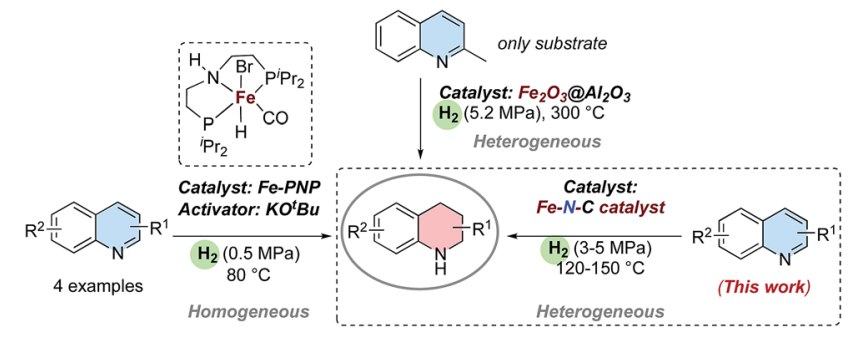

- Supported Nanostructured Fe-Catalyst reactivity tuned by $N$-doped Carbon (NC) reused upto 7 th run without loss of efficacy

Broad Substrate Scope (>32 examples) applied in drugs and chromophore synthesis Good Functional Group (FG) Tolerance
range of FGs (e.g. CN, CONR 2 , etc.) survived

Fig. 1 Iron-catalyzed hydrogenations of quinolines.

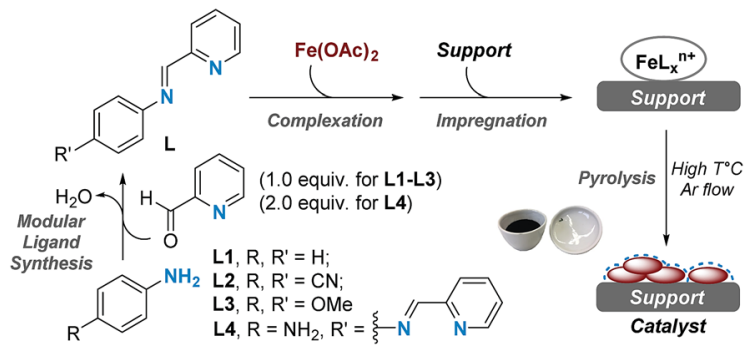

Scheme 1 General procedure for the synthesis of Fe-based materials.

metal oxide particles modified by a N-doped carbon matrix and applied them in redox reactions, such as the reduction of nitroarenes, nitriles and ketones as well as the oxidation of alcohols..$^{15}$ The synergistic combination of metal/metal oxide nanoparticles and $\mathrm{N}$-doped carbon, originating from ligands upon pyrolysis, turned out to be crucial for the desired reactivity and excellent selectivity. ${ }^{13 c, d, 14,15}$ Since nitrogen doping into the carbon matrix has a substantial influence on the catalytic activity of metal/metal oxide nanoparticles, ${ }^{13 d, 15 d, 16}$ the selection of the N-donor ligand is critical to access high reactivity and it mostly remains limited to 1,10 -phenanthroline. Intriguingly, finding alternative ligands to 1,10-phenanthroline would be a significant step forward in the context of the development of catalytically active materials. ${ }^{7 b, 14 b-e, 15 a-d}$

Herein, we report a series of novel supported Fe-based materials modified by a N-doped carbon matrix, generated from bidentate $N$-aryliminopyridine ligands upon pyrolysis. Utilization of the optimal material allowed for the first heterogeneous iron-catalyzed hydrogenation of substituted (iso)quinolones with synthetic value.

\section{Results and discussion}

We set out our study with the preparation of a range of Fe-based materials in a sequential process: (a) modular synthesis of $\mathrm{N}$ donor aryliminopyridine ligands via Schiff base condensation; (b) complexation with $\mathrm{Fe}(\mathrm{OAc})_{2}(\mathrm{OAc}=$ acetate $) ;{ }^{17}$ (c) deposition by wet impregnation of complexes onto suitable supports; and (d) drying and pyrolysis at variable temperatures $\left(500-900{ }^{\circ} \mathrm{C}\right)$ based on thermogravimetric (TG) analysis (Scheme 1 and Fig. S1† respectively). ${ }^{18}$

Having a library of novel Fe-based materials, we began exploring their catalytic activity in the hydrogenation of

Table 1 Fe-catalysed hydrogenation of quinoline ${ }^{a}$

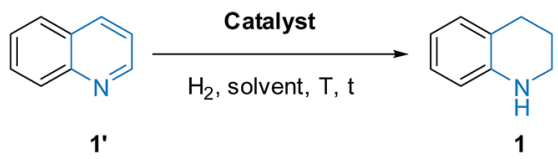

\begin{tabular}{|c|c|c|c|c|c|c|}
\hline 1 & Fe(1)/L1(3.0)@C-800 (12) & ${ }^{\mathrm{i}} \mathrm{PrOH}$ & 5 & 140 & 28 & $16(16)$ \\
\hline 2 & $\mathrm{Fe}(1) / \mathrm{L} 2(3.0) @ \mathrm{C}-800(12)$ & ${ }^{\mathrm{i}} \mathrm{PrOH}$ & 5 & 140 & 28 & $12(12)$ \\
\hline 4 & $\mathrm{Fe}(1) / \mathbf{L} 4(1.5) @ \mathrm{C}-800(12)$ & ${ }^{\mathrm{i}} \mathrm{PrOH}$ & 5 & 140 & 28 & $55(50)$ \\
\hline 5 & $\mathrm{Fe}(1) / \mathbf{L} 4(1.5) @ \mathrm{C}-800(12)$ & ${ }^{\mathrm{i}} \mathrm{PrOH}$ & 5 & 140 & 24 & $45(45)$ \\
\hline 6 & $\mathrm{Fe}(1) / \mathbf{L} 4(1.5) @ \mathrm{C}-800(12)$ & ${ }^{\mathrm{i}} \mathrm{PrOH} / \mathrm{H}_{2} \mathrm{O}(3 / 1)$ & 5 & 140 & 24 & $52(52)$ \\
\hline 9 & $\mathrm{Fe}(1) / \mathbf{L 4}(6.0) @ \mathrm{C}-800(12)$ & ${ }^{\mathrm{i}} \mathrm{PrOH} / \mathrm{H}_{2} \mathrm{O}(3 / 1)$ & 5 & 140 & 24 & $91(82)$ \\
\hline 10 & $\mathrm{Fe}(1) / \mathbf{L} 4(4.5) @ \mathrm{C}-800(12)$ & ${ }^{\mathrm{i}} \mathrm{PrOH} / \mathrm{H}_{2} \mathrm{O}(3 / 1)$ & 5 & 140 & 30 & $>99(85)$ \\
\hline 11 & $\mathrm{Fe}(1) / \mathbf{L} 4(4.5) @ \mathrm{C}-800(12)$ & ${ }^{\mathrm{i}} \mathrm{PrOH} / \mathrm{H}_{2} \mathrm{O}(3 / 1)$ & 5 & 130 & 30 & $80(73)$ \\
\hline 12 & $\mathrm{Fe}(1) / \mathbf{L 4}(4.5) @ \mathrm{C}-800(12)$ & ${ }^{\mathrm{i}} \mathrm{PrOH} / \mathrm{H}_{2} \mathrm{O}(3 / 1)$ & 5 & 120 & 30 & $47(45)$ \\
\hline 13 & $\mathrm{Fe}(1) / \mathrm{L} 4(4.5) @ \mathrm{C}-800(12)$ & ${ }^{\mathrm{i}} \mathrm{PrOH} / \mathrm{H}_{2} \mathrm{O}(\mathbf{3} / \mathbf{1})$ & 4 & 130 & 56 & $>99(87)$ \\
\hline 14 & $\mathrm{Fe}(1) / \mathbf{L} \mathbf{4} / \mathrm{C}(\sim 12)$ & ${ }^{\mathrm{i}} \mathrm{PrOH} / \mathrm{H}_{2} \mathrm{O}(3 / 1)$ & 4 & 130 & 56 & - \\
\hline
\end{tabular}

${ }^{a}$ Reaction conditions: $1 \mathrm{a}(0.2 \mathrm{mmol})$ and Fe-catalyst $(12 \mathrm{~mol} \% \mathrm{Fe})$ in solvent $(1 \mathrm{~mL})$ heated in the presence of $\mathrm{H}_{2} \cdot{ }^{b}$ Determined by GC analysis using hexadecane as the internal standard. ${ }^{c}$ GC yield reported in parentheses. ${ }^{d}$ Reaction was performed in the presence of nitrogen (4 MPa). 
quinolines. In an initial set of experiments with quinoline $\left(\mathbf{1}^{\prime}\right)$ in ${ }^{\mathrm{i}} \mathrm{PrOH}$ in the presence of $\mathrm{H}_{2}(5 \mathrm{MPa})$ at $140{ }^{\circ} \mathrm{C}$ for $28 \mathrm{~h}$, the materials which were prepared from four different ligands (L1L4) on the carbon support exhibited desired reactivity and the catalyst with $\mathbf{L 4}$ remained relatively more efficient (Table 1, entries 1-4). However, altering the support with L4 did not improve the conversion (Table $\mathrm{S} 4, \dagger$ entries $5-7) .{ }^{18}$ Additionally, the screening of materials prepared over a wide range of pyrolysis temperatures $\left(500-900{ }^{\circ} \mathrm{C}\right)$ revealed the best efficiency of the catalyst which was prepared at $800{ }^{\circ} \mathrm{C}$ (Table S1, $\dagger$ entries 4 and $8-11) .{ }^{18}$ Testing polar and non-polar solvents alone did not increase product formation (Table S1, $\dagger$ entries 12-14), ${ }^{18}$ whereas a mixture of ${ }^{\mathrm{i}} \mathrm{PrOH} / \mathrm{H}_{2} \mathrm{O}(3 / 1)$ enhanced the conversion slightly (Table 1, entries 5 and 6). Next, inspired by the metal-toligand ratio effect on the catalytic activity in the dehydrogenation of formic acid, ${ }^{19}$ we synthesized an array of catalysts with various $\mathrm{Fe}(\mathrm{OAc})_{2} / \mathbf{L} 4$ ratios. To our surprise, the set of four catalysts with different $\mathrm{Fe} / \mathbf{L} 4$ ratios $(1: 1.5$ to $1: 6.0)$ exhibited a dramatic enhancement of reaction efficiency (Table 1, entries 6-9). The progress of tetrahydroquinoline (1) formation with time resulted in the following reactivity pattern: $\mathrm{Fe}(1) / \mathbf{L} 4(4.5)$ (aC-800 > Fe(1)/L4(6.0)@C-800 > Fe(1)/L4(3.0)@C-800 > Fe(1)/ L4(1.5)@C-800 (Fig. 2). Full conversion was achieved at $150{ }^{\circ} \mathrm{C}$ and $5 \mathrm{MPa}$ hydrogen pressure after $30 \mathrm{~h}$ (Table 1, entries 10). Nevertheless, hydrogenation to $\mathbf{1}$ ( $87 \%$ GC yield) is also possible at lower temperature and pressure for a prolonged reaction time (Fe(1)/L4(4.5)@C-800 (12 mol\% Fe) in ${ }^{\mathrm{i}} \mathrm{PrOH} / \mathrm{H}_{2} \mathrm{O}(3 / 1), \mathrm{H}_{2}$ (4 MPa), $130{ }^{\circ} \mathrm{C}, 56 \mathrm{~h}$ ) (Table 1 , entry 13 ). For the success of this hydrogenation reaction, the presence of the ligand and metal as well as the pyrolysis process remains crucial. Consequently, no reactivity was observed in the presence of Fe@C-800, L4@C-800 and unpyrolyzed $\mathrm{Fe}(1) / \mathbf{L} \mathbf{4}(4.5) / \mathrm{C}$ composites (Table 1, entries 14-16). No conversion is observed carrying out the reaction in the presence of nitrogen (4 MPa) used instead of hydrogen, which excludes transfer hydrogenation with isopropanol (Table 1 , entry 17$)$.

The composition of the catalysts was determined by elemental analysis. Interestingly, an ascending order of nitrogen amount and a descending order of iron content were

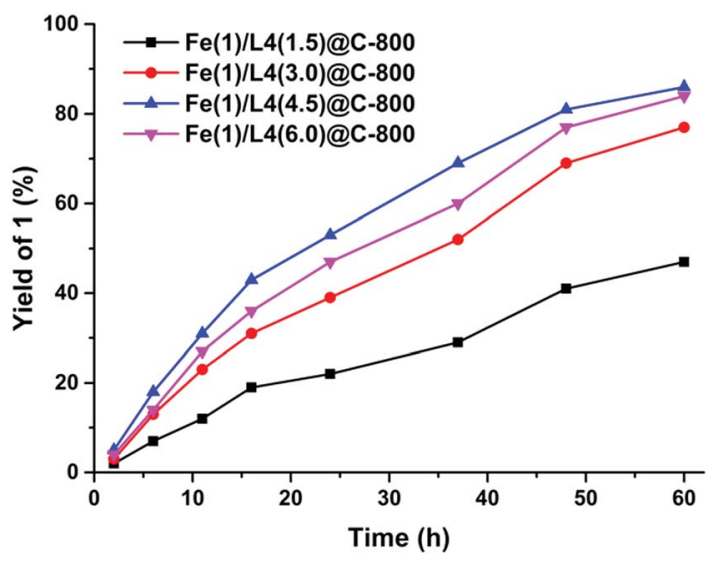

Fig. 2 Product yield/time profile for the comparison between Fecatalysts with different metal-to-ligand ratios under standard conditions. noticed when the metal-to-ligand ratio was changed in the preparation process from $1: 1.5$ to $1: 6.0$ (Table S2 $\dagger$ ). ${ }^{18}$ The structural characteristics of selected materials were investigated by means of various techniques, such as powder XRD, STEM, XPS and Raman spectroscopy. Investigating the bulk phase of the materials, the powder X-ray diffraction measurements demonstrated the presence of iron carbide $\left(\mathrm{Fe}_{3} \mathrm{C}\right)$ as a major iron constituent along with additional metallic $\mathrm{Fe}(0)$ and $\mathrm{FeN}_{x}$ in both the catalysts: $\mathrm{Fe}(1) / \mathbf{L 4}(4.5) @ \mathrm{C}-800$ and $\mathrm{Fe}(1) / \mathbf{L 4}(1.5) @ \mathrm{C}-$ 800 , while the main components in the almost inactive $\mathrm{Fe}(1) /$ $\mathbf{L 4}(1.5) @ \mathrm{C}-500$ are iron oxides (e.g. $\mathrm{Fe}_{3} \mathrm{O}_{4}$ ) along with the obvious reflections for carbon in all these materials (Fig. 3 and $\mathrm{S} 2 \dagger) .{ }^{18}$ Interestingly, the iron oxide $\left(\mathrm{Fe}_{3} \mathrm{O}_{4}\right)$ phase was formed at lower pyrolysis temperatures $\left(500-600{ }^{\circ} \mathrm{C}\right)$, while the formation of metallic $\mathrm{Fe}(0)$ and iron carbide $\left(\mathrm{Fe}_{3} \mathrm{C}\right)$ was observed at higher pyrolysis temperatures $\left(700-900{ }^{\circ} \mathrm{C}\right)$, likely stemming from the iron oxides (Fig. 3). ${ }^{20}$

The electronic structure and surface elemental composition were determined by X-ray photoelectron spectroscopy (XPS) (Table S3†). ${ }^{18}$ The N1s spectra for the above-mentioned materials displayed two different peaks (Fig. S7a $\dagger$ ). Due to similar electron binding energy (B.E.) a univocal assignment is not possible. The lower peak can be ascribed to the pyridinic nitrogen and/or nitrogen bound to the metal ion $\left(\mathrm{Fe}-\mathrm{N}_{x}\right)$, while the higher one resembles graphitic and/or pyrrolic nitrogen. ${ }^{21,22 a}$ Additionally, Fe2p spectra of all samples exhibited two wide peaks centered around 711.5 and $725 \mathrm{eV}$ due to $2 \mathrm{p}_{3 / 2}$ and $2 \mathrm{p}_{1 / 2}$ contributions, respectively (Fig. 4). Broadening of the peak is a hint of heterogeneity of the Fe phase present on the surface of the sample. According to TEM and literature data, this contribution is ascribed to the Fe-N bond but other Fe species in high oxidation states cannot be excluded. ${ }^{20,22}$ In addition, $\mathrm{Fe}(1) / \mathbf{L 4}(4.5) @ \mathrm{C}-800$ and Fe(1)/L4(1.5)@C-800 samples clearly exhibit a contribution at a lower binding energy around $709 \mathrm{eV}$ attributed to iron carbide $\left(\mathrm{Fe}_{3} \mathrm{C}\right){ }^{20}$ The aberration corrected scanning transmission electron microscopy (STEM) high angle annular dark field (HAADF) overview images of less active $\mathrm{Fe}(1)$ /

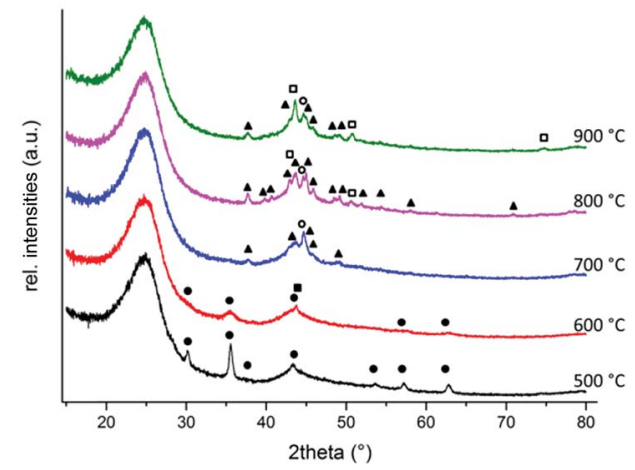

Fig. 3 Powder X-ray diffraction pattern of the $\mathrm{Fe}(1) / \mathrm{L} 4(1.5)$ aC- $\mathrm{T}$ catalyst at different pyrolysis temperatures $\left(T=500{ }^{\circ} \mathrm{C}\right.$ (black), $T=$ $600^{\circ} \mathrm{C}$ (red), $T=700^{\circ} \mathrm{C}$ (blue), $T=800^{\circ} \mathrm{C}$ (purple) and $T=900{ }^{\circ} \mathrm{C}$ (green)). Phases are shown as filled circles $\left(\mathrm{Fe}_{3} \mathrm{O}_{4}, \mathrm{ICDD}\right.$ 01-0842782), filled squares ( $\left.\mathrm{Fe}_{3} \mathrm{~N}, \mathrm{ICDD} 01-083-0878\right)$, triangles $\left(\mathrm{Fe}_{3} \mathrm{C}, \mathrm{ICDD}\right.$ 00-034-0001), empty circles (Fe, ICDD 00-006-0696), and empty squares $\left(\mathrm{FeN}_{x}, \mathrm{ICDD}\right.$ 01-075-2127). 


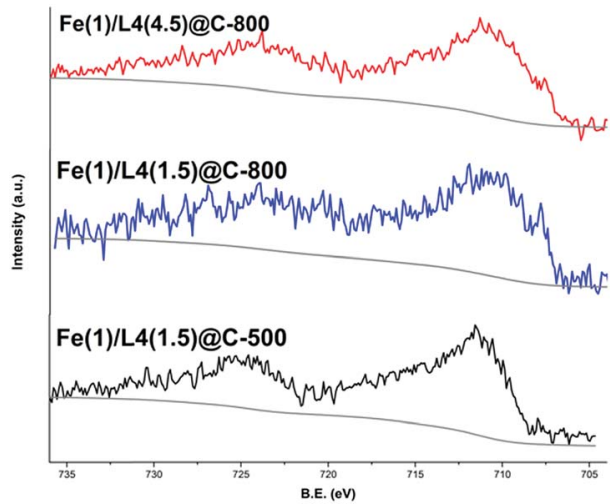

Fig. 4 Fe2p XPS spectra of Fe-based materials: Fe(1)/L4(4.5)@C-800 (red), Fe(1)/L4(1.5)@C-800 (blue) and Fe(1)/L4(1.5)@C-500 (black).

L4(1.5)@C-800 (Fig. 5a) and most active Fe(1)/L4(4.5)@C-800 (Fig. 5b) catalysts were acquired together with electron energy loss spectroscopy (EELS) and energy dispersive X-ray spectroscopy (EDXS). In both catalysts, the iron containing particles, probably iron carbide according to $\mathrm{XRD}$, are generally surrounded by a few to many graphene layers forming a seemingly tight enclosure. Additionally, there is a carbon phase probably stemming from the ligand, as it also contains small amounts of nitrogen (Fig. $5 \mathrm{c}$ and d, and $\mathrm{S} 10-12 \dagger) .{ }^{18}$ In the Fe(1)/L4(1.5)@C800 catalyst, the additional nitrogen containing carbon structure seems to contain larger clusters of iron atoms (Fig. S12 $\dagger$ ) than in the $\mathrm{Fe}(1) / \mathbf{L 4}(4.5) @ \mathrm{C}-800$ catalyst, where aberration corrected high resolution STEM-HAADF images suggest the presence of finely distributed atoms and very small clusters of a heavier kind than carbon (Fig. 5e, S10 and S11†), ${ }^{18}$ attributed to Fe. Moreover, carbon nanotubes could be observed in the $\mathrm{Fe}(1) / \mathbf{L 4}(4.5) @ \mathrm{C}-800$ catalyst, while they were rarely noticed in the $\mathrm{Fe}(1) / \mathbf{L} 4(1.5) @ \mathrm{C}-800$ catalyst (Fig. S11 and S12†). ${ }^{18}$ The STEM data of almost inactive $\mathrm{Fe}(1) / \mathbf{L 4}(1.5) @ \mathrm{C}-500$, prepared by pyrolysis at $500{ }^{\circ} \mathrm{C}$, showed the parallel occurrence of nitrogen and iron in fine distribution in some regions. Also, iron oxide particles and a few iron/iron oxide core shell type particles were present (Fig. S13†).$^{18}$ In further analysis by Raman spectroscopy, two peaks were observed at $\sim 1590 \mathrm{~cm}^{-1}$ (G band) and $\sim 1343 \mathrm{~cm}^{-1}$ (D band) in each material (Fig. S15 and Table $\mathrm{S} 4 \dagger) .{ }^{18,23}$ Notably, the occurrence of the D band signified the presence of defects in the graphitic carbon matrix.

With the optimal reaction conditions in hand, we sought to explore the synthetic scope and limitations of this transformation, which are summarized in Scheme 2. A variety of quinolines with diverse substitution patterns and functionalities were employed under the developed protocol for the selective hydrogenation. At first, 2-substituted quinolines, for example, quinaldine and 2-phenylquinoline were selectively hydrogenated to corresponding 1,2,3,4-tetrahydroquinaldine (2), an intermediate for the synthesis of antitrypanosomal lead compounds, ${ }^{24}$ and 2-phenyl-1,2,3,4-tetrahydroquinoline (3), respectively, in excellent yields (both 98\%). Furthermore, 3-methyl-1,2,3,4-tetrahydroquinoline $(4,90 \%)$ and 3-(4methoxyphenyl)-1,2,3,4-tetrahydroquinoline $(5,91 \%)$ were
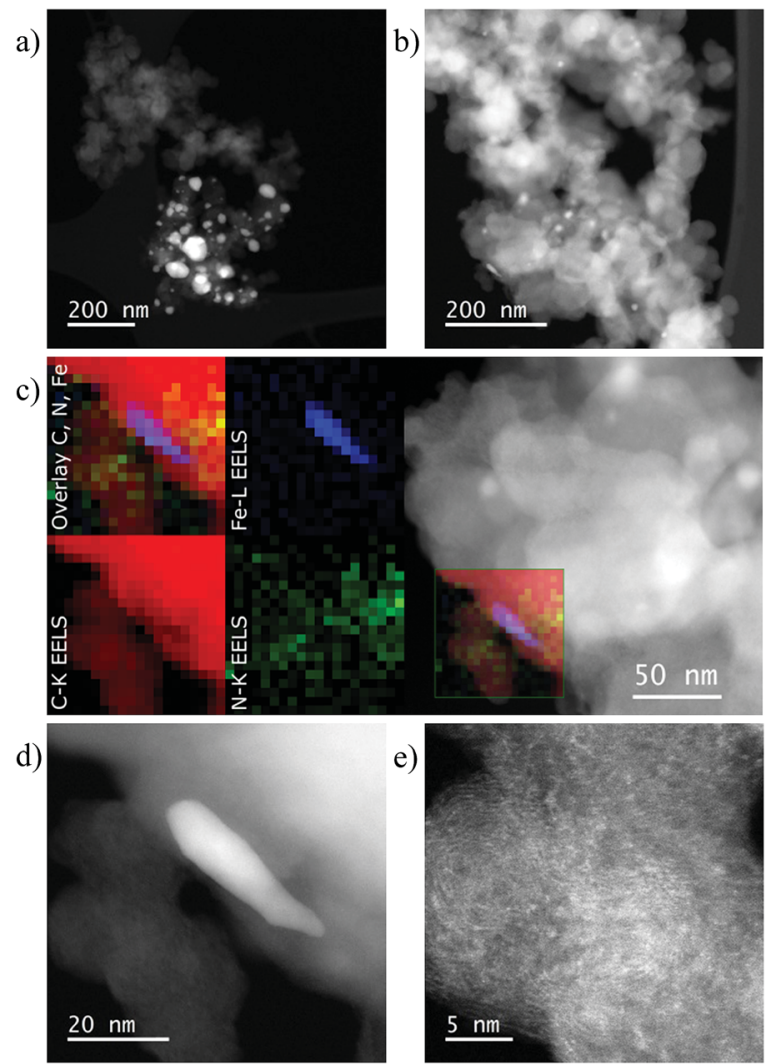

Fig. 5 STEM-HAADF overview images of Fe(1)/L4(1.5)@C-800 (a) and $\mathrm{Fe}(1) / L 4(4.5) \mathrm{aC}-800$ (b), STEM-ADF image (c) of the lower left area of (b) overlaid with the false color image of the elemental distributions of $\mathrm{C}, \mathrm{N}$ and $\mathrm{Fe}$ calculated from the electron energy loss spectrum imaging data set of the marked area; STEM-HAADF images with higher magnification showing details of the spectrum imaging area (d) and the extra carbon phase containing nitrogen (e) attached to the support.

successfully prepared from the corresponding quinoline substrates. More interestingly, a 2,3-disubstituted quinoline was hydrogenated to afford 1,2,3,4-tetrahydroquinoline derivative 6 in good yield $(77 \%$; d.r. $=1.3: 1)$, whereas 2,4 -dimethylquinoline was converted to 2,6-dimethyl-1,2,3,4tetrahydroquinoline (7) in good yield (77\%) and moderate diastereoselectivity (d.r. $=4.5: 1$ ) without arene ring hydrogenation. Aside from the pyridine ring, different substituents at the 6-position of quinoline survived under the employed hydrogenation conditions. Here, 6-isopropylquinoline was converted to 8 in moderate yield (67\%). Furthermore, quinoline derivatives featuring 4-fluorophenyl and 4-trifluoromethoxyphenyl and a pyrazole moiety were successfully hydrogenated to the corresponding 1,2,3,4-tetrahydroquinoline congeners 9-11 in good to excellent yields. Gratifyingly, substituted quinaldine substrates have been proven to be suitable candidates for this selective hydrogenation reaction, too. Electron-rich 6-methoxyquinaldine and electron-deficient 6- and 7-fluoroquinaldine were selectively converted to pyridine core hydrogenation products 12 (95\%), 13 (94\%) and 14 (88\%), respectively, with almost equal efficiency. Furthermore, sterically hindered 8methyl-1,2,3,4-tetrahydroquinaldine (15) was also furnished in 

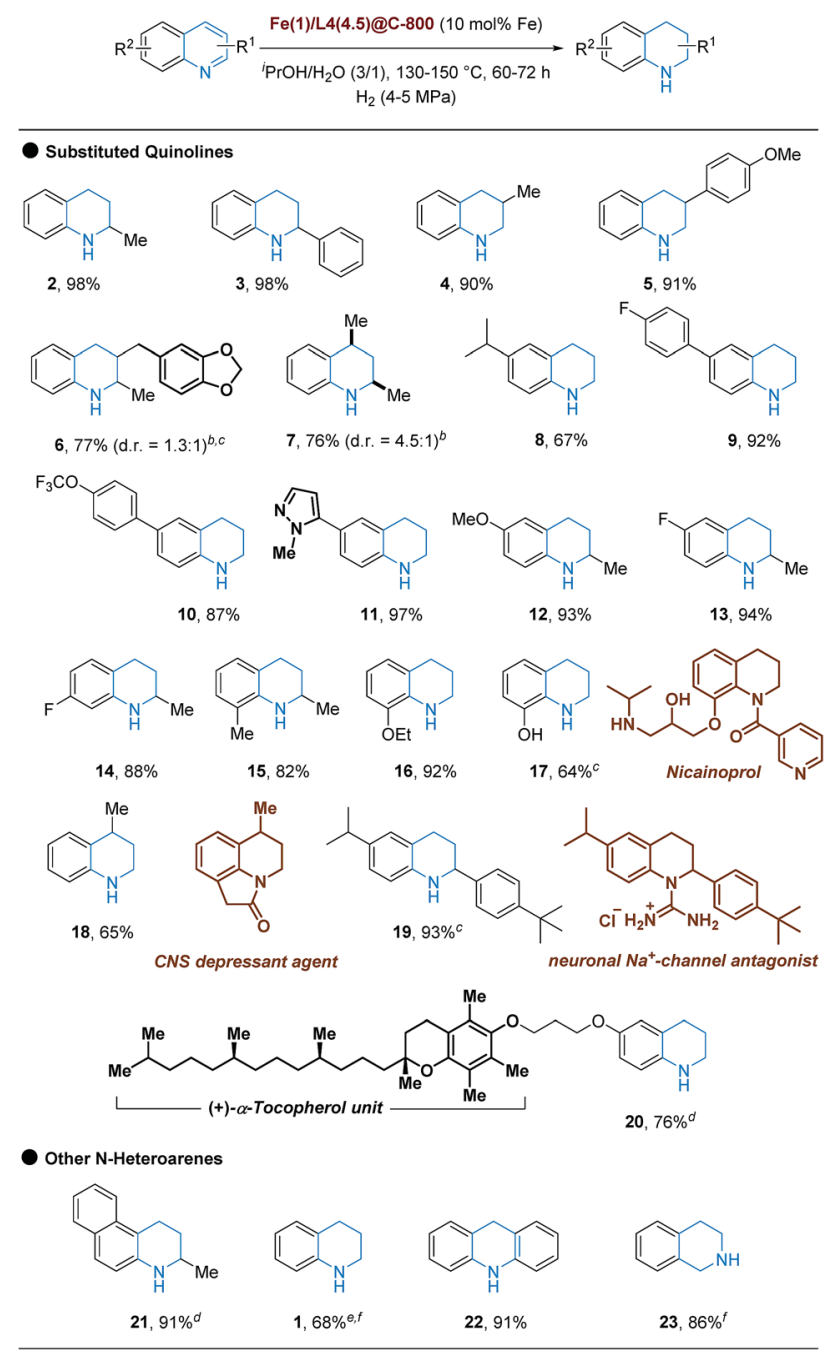

Scheme 2 Selective hydrogenation of $\mathrm{N}$-heteroarenes ${ }^{\mathrm{a}}$. ${ }^{\mathrm{a}}$ Reaction conditions: substrate $(0.32-0.50 \mathrm{mmol})$ and $\mathrm{Fe}(1) / \mathrm{L} 4(4.5) \mathrm{CC}-800$ (10 mol\% Fe) in ${ }^{\mathrm{i}} \mathrm{PrOH} / \mathrm{H}_{2} \mathrm{O}(3 / 1)(2-2.5 \mathrm{~mL})$, heated at $130-150{ }^{\circ} \mathrm{C}$ in the presence of $\mathrm{H}_{2}(4-5 \mathrm{MPa})$, all yields are isolated unless otherwise mentioned (see ESI $\uparrow$ for details); ${ }^{b}$ d.r. was determined by GC analysis; ${ }^{\mathrm{C}} \mathrm{Fe}(1) / \mathrm{L} 4(4.5) \mathrm{aC}-800$ (12 mol\% Fe) was used; ${ }^{\mathrm{F}} \mathrm{Fe}(1) / \mathrm{L} 4(4.5) @ \mathrm{CC}-800$ (15 mol\% Fe) was used; ' quinoline- $N$-oxide was used as the substrate; ${ }^{f} \mathrm{GC}$ yield was determined by $\mathrm{GC}$ analysis using hexadecane as the internal standard

very good yield (88\%). In addition to the ethyl protected 8-quinolinol, which was easily converted to the reduced product 16 (92\%) in excellent yield, a more challenging substrate 8-quinolinol with a free hydroxyl group was also transformed into the corresponding 1,2,3,4-quinolin-8-ol (17, 64\%), which constitutes a substructure of nicainoprol. ${ }^{25}$ Notably, the more challenging lepidine substrate was also hydrogenated to the corresponding 1,2,3,4-tetrahydrolepidine (18, 65\%), which serves as a precursor for the synthesis of a central nervous system (CNS) depressant agent. ${ }^{26}$ Furthermore, 2-(4-(tert-butyl) phenyl)-6-isopropyl-1,2,3,4-tetrahydroquinoline (19), a key intermediate for the synthesis of a neuronal $\mathrm{Na}^{+}$-channel antagonist, ${ }^{27}$ was also afforded in high yield (93\%). Interestingly, a quinoline substrate bioconjugated with $(+)-\alpha-$ tocopherol (vitamin E) was also successfully employed to furnish the selective hydrogenation product $\mathbf{2 0}$ in good yield (76\%). Besides quinolines, this novel hydrogenation method could also be extended to benzannulated quinolines, such as 3methylbenzo[f]quinoline and acridine, and even (iso)quinolone to deliver the corresponding hydrogenated products $\mathbf{1}$, 21-23 in moderate to excellent yields.

To address the often asked question of scalability, a gram scale synthesis of 6-fluoro-1,2,3,4-tetrahydroquinaldine (13), which is a key intermediate for the synthesis of flumequine (antibiotic), ${ }^{8 f}$ starting from 6-fluoroquinaldine $\left(\mathbf{1 3}^{\prime}\right)$ was executed without hampering efficiency under standard conditions with an even reduced catalyst amount (8 mol\% Fe loading) (Scheme 3).

Obviously, chemoselective reduction of (iso)quinolones in the presence of other reducible functional groups constitutes a major challenge in catalytic hydrogenations, especially for life science molecules. ${ }^{5}$ Intrigued by this task, we tested several substrates bearing redox-sensitive nitriles, esters, amides, halogens, and heteroarenes (Table 2).

Delightfully, a 6-arylquinoline substrate featuring a nitrile group was successfully converted to the corresponding $1,2,3,4$ tetrahydroquinoline congener 24 in good yield (78\%) keeping nitrile intact. Methyl 1,2,3,4-tetrahydroquinoline-6-carboxylate (25) could also be obtained without reduction of the ester group, albeit in moderate yield, while an (iso)quinolone derivative featuring a tertiary amide moiety was successfully hydrogenated to 1,2,3,4-tetrahydroisoquinoline 29 in $71 \%$ yield without amide hydrogenation. Interestingly, quinaldines bearing chlorine substituents at 6- and 7-positions furnished 1,2,3,4-tetrahydroquinaldines 26 and 27 in 70 and $77 \%$ yield, respectively. However, small amounts of the hydrodechlorination product $2(7 \%)$ were detected in the case of $\mathbf{2 6}$, too. Notably, a quinoline substrate featuring a thiophene unit at the 8-position was also hydrogenated to 8-(thiophen-3-yl)1,2,3,4-tetrahydroquinoline $(\mathbf{2 8}, \mathbf{8 9} \%)$ in very good yield.

Aside from exploring the general scope, the multistep synthesis of natural products as well as medicinally important lead compounds was performed as a proof-of-applicability. Hence, the Fe-catalyzed hydrogenation was utilized as a key step in converting 2 - $n$-pentylquinoline $\left(\mathbf{3 0}^{\prime}\right)$ to $( \pm)$-angustureine $(31)^{8 e}$ in two steps (Scheme 4). Furthermore, commercially available 6-methoxyquinoline $\left(\mathbf{3 2}^{\prime}\right)$ was transformed to 6methoxy-1,2,3,4-tetrahydroquinoline (32, 95\%), which was further converted to a tubulin polymerization inhibitor $(33)^{8 g}$ (Scheme 4). Finally, the pharmaceutically important lead compound 37 of histamine $\mathrm{H}_{3}$-receptor antagonist was synthesized in four steps starting from readily available 6-quinolinol, which represents an attractive alternative to the noble metal catalyzed process (Scheme 4$){ }^{\mathbf{}}{ }^{\text {h }}$

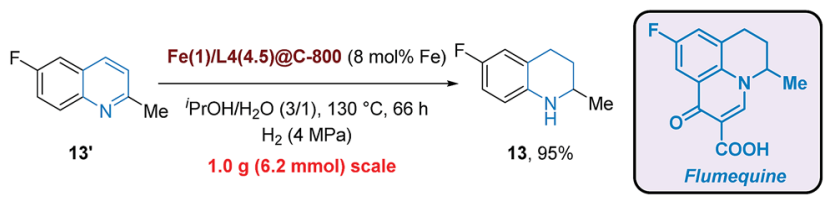

Scheme 3 Quinoline hydrogenation: Gram-scale reaction. 
Table 2 Chemoselective hydrogenation of $\mathrm{N}$-heteroarenes ${ }^{a}$
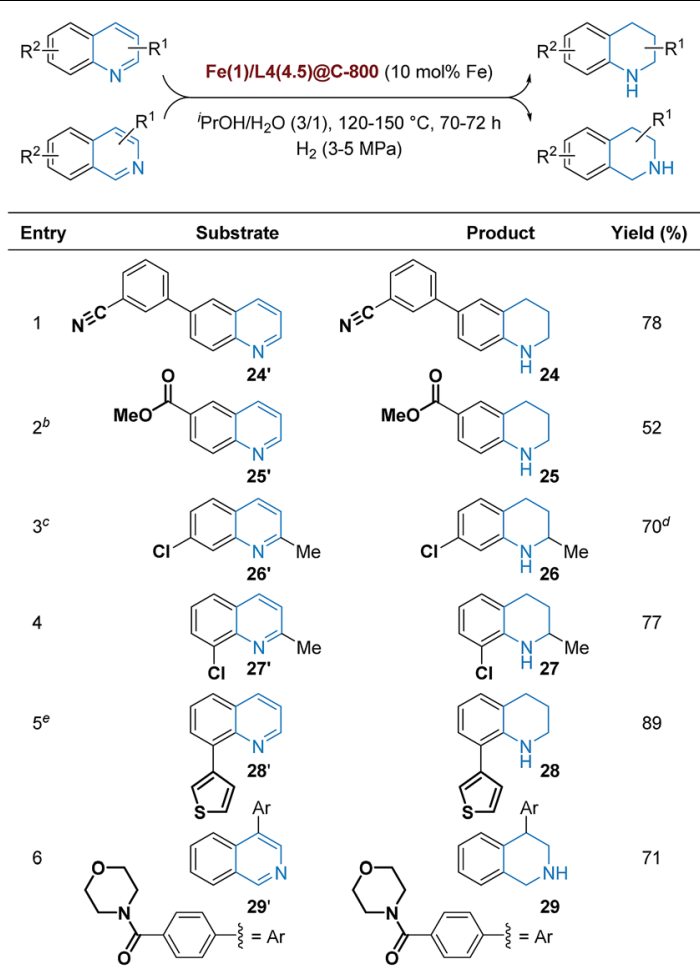

${ }^{a}$ Reaction conditions: substrate $(0.25-0.40 \mathrm{mmol})$ and $\mathrm{Fe}(1) / \mathbf{L} 4(4.5) @ \mathrm{C}-$ $800(10 \mathrm{~mol} \% \mathrm{Fe})$ in ${ }^{\mathrm{i}} \mathrm{PrOH} / \mathrm{H}_{2} \mathrm{O}(3 / 1)(1.2-2.0 \mathrm{~mL})$, heated at $120-150{ }^{\circ} \mathrm{C}$ for 70-72 $\mathrm{h}$ in the presence of $\mathrm{H}_{2}$ (3-5 MPa), all yields are isolated unless otherwise mentioned (see ESI for details). ${ }^{b}$ Reaction was performed in $\mathrm{MeOH} / \mathrm{H}_{2} \mathrm{O}(3 / 1) .{ }^{c}$ Reaction was carried out at $120{ }^{\circ} \mathrm{C}$ and $\mathrm{H}_{2}(3 \mathrm{MPa})$. ${ }^{d}$ Hydrodechlorination product 2 could be detected in $7 \%$ yield. ${ }^{e} \mathrm{Fe}(1) / \mathbf{L} 4(4.5) @ \mathrm{C}-800$ (15 mol\% Fe) was used.

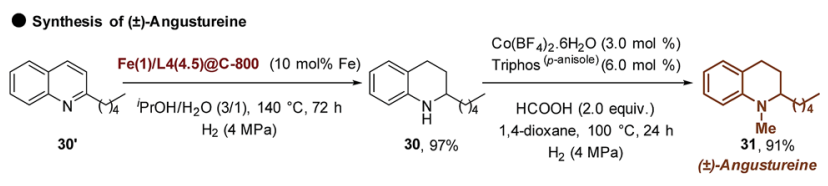

- Synthesis of Tubulin Polymerization Inhibitor

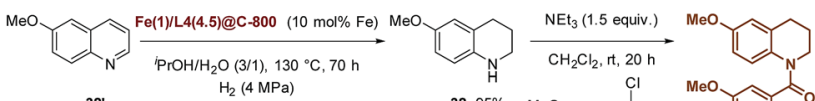
32 $32,95 \%$
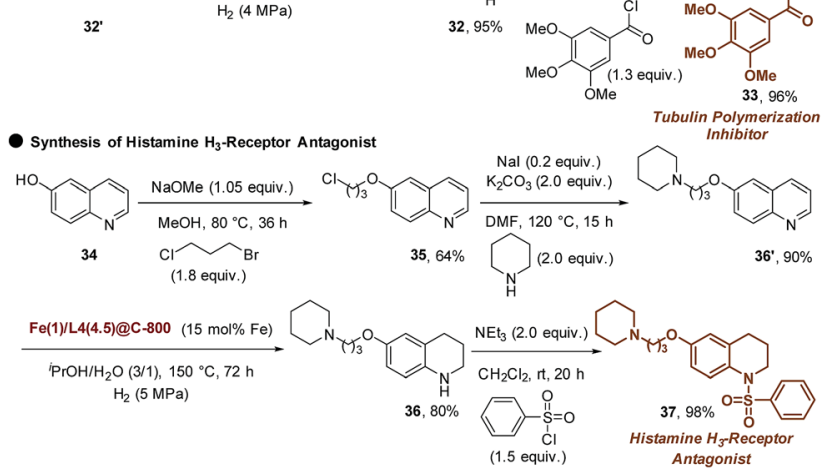

Scheme 4 Applications in the bioactive compound synthesis.

Additionally, the developed technology proved to be a useful tool to convert 6-pyrenequinoline-based photoluminescent materials $\left(\mathbf{3 8}^{\prime} \text { and } 39^{\prime}\right)^{28}$ to analogous congeners (38 and $\mathbf{3 9}$,
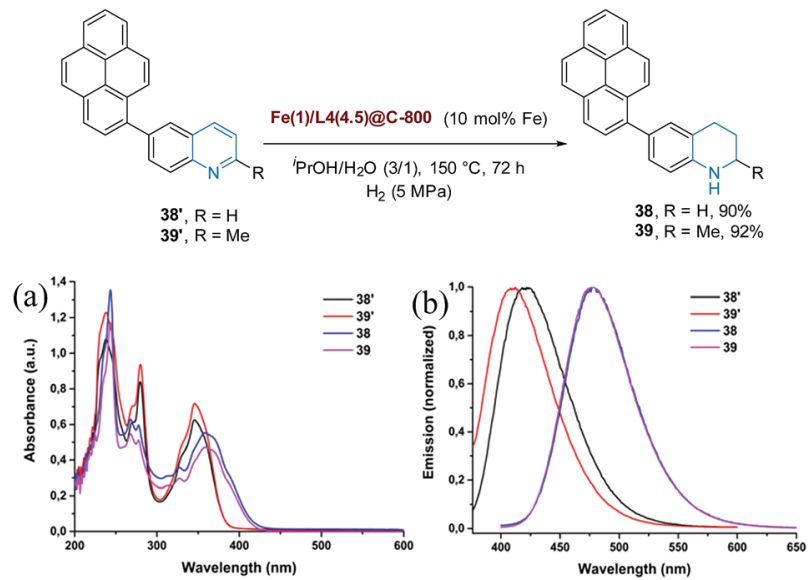

Fig. 6 Applications in the conversion of photoactive materials (a) UVVis spectra and (b) Emission spectra of compounds 38' (20 $\mu \mathrm{M}), 39^{\prime}$ $(20 \mu \mathrm{M}), 38(20 \mu \mathrm{M})$ and $39(20 \mu \mathrm{M})$ in dichloromethane.
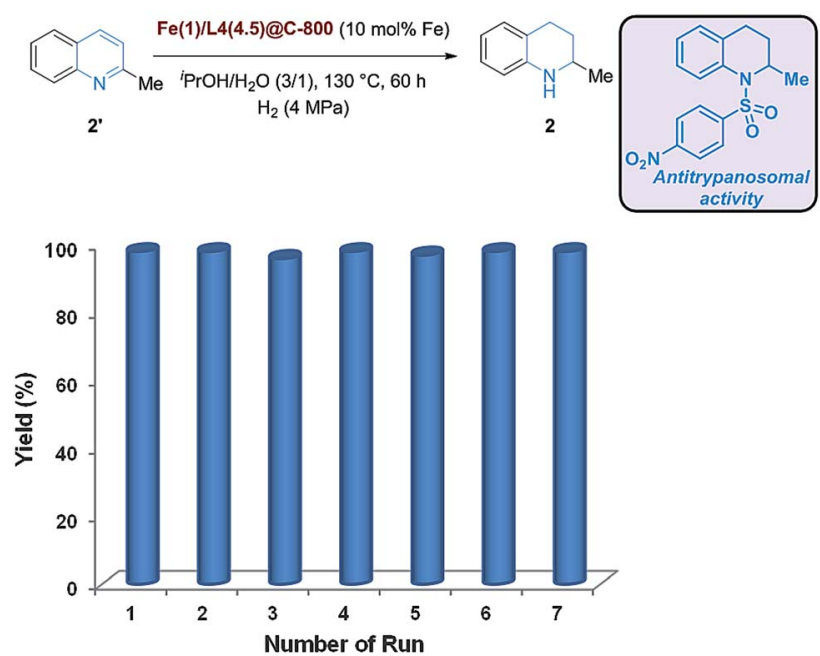

Fig. 7 Catalyst recycling tests: hydrogenation of quinaldine.

respectively) (Fig. 6). As noticed in the UV-Vis absorption as well as emission spectra, a clear bathochromic-shift of absorption and emission wavelengths altering photophysical properties was observed due to selective hydrogenation (Fig. 6).

Since the recycling and reusability of the catalyst constitute a crucial advantage in heterogeneous catalysis, the optimal Fecatalyst, $\mathrm{Fe}(1) / \mathbf{L} 4(4.5) @ \mathrm{C}-800$, was employed seven times for the hydrogenation of quinaldine $(4.0 \mathrm{mmol} \mathrm{scale})$. To our delight, the catalyst could be recycled and reused without a significant drop of reactivity to obtain the desired 1,2,3,4-tetrahydroquinaldine (2) in almost quantitative yield (Fig. 7 and Table $\mathrm{S} 5 \dagger$ ). Notably, some $\mathrm{Fe}_{3} \mathrm{O}_{4}$ particles appeared in the reused catalyst compared to the fresh catalyst (Fig. S3†). ${ }^{18}$

\section{Conclusions}

We have developed the first heterogeneous Fe-catalyst for the selective hydrogenation of quinolines and (iso)quinolones 
using molecular hydrogen as a clean reducing agent. The optimal catalyst is easily prepared from commercially available iron acetate and $\mathrm{N}$-aryliminopyridines. This robust material can be conveniently handled and is stable towards air and moisture, which provides the basis for simple catalyst recycling. A variety of quinolines with diverse substitution patterns and functionalities were successfully converted to 1,2,3,4-tetrahydroquinolines in moderate to excellent yields with high selectivity, even in the presence of other reducible functional groups, such as nitriles, halogens, esters, amides and heteroarenes. The value of this methodology is showcased by the synthesis of bioactive molecules as well as the modification of photoactive materials. It is worth mentioning that the presented Schiff base condensation of 2-pyridinecarboxaldehyde with commercially available anilines allows for the design of an infinite number of new potential catalysts for various other applications.

\section{Conflicts of interest}

There are no conflicts to declare.

\section{Acknowledgements}

This work was supported by the state of Mecklenburg Vorpommern and F. Hoffmann-La Roche AG. We thank Dr Wolfgang Baumann, Dr Dario Formenti, Dr Wu Li, Dr AnnetteEnrica Surkus, Kathiravan Murugesan and Thirusangumurugan Senthamarai (all LIKAT Rostock) for experimental assistance and helpful discussions. We also thank Dr Nils Rockstroh, Dr C. Fischer, S. Buchholz, S. Schareina, Mrs Anja Simmula, Mrs Astrid Lehmann and Mr Alexander Wolzka (all LIKAT Rostock) for experimental and analytical assistance.

\section{References}

1 Selected reviews and books: (a) A. Gualandi and D. Savoia, RSC Adv., 2016, 6, 18419; (b) T. J. Donohoe, R. Garg and C. A. Stevenson, Tetrahedron: Asymmetry, 1996, 7, 317; (c) T. J. Donohoe, C. R. Jones, and C. Winter, in Comprehensive Organic Synthesis II, Elsevier, Amsterdam, 2nd edn, 2014.

2 (a) P. G. Andersson, and I. J. Munslo, Modern Reduction Methods, Wiley, New York, 2008; (b) J. G. De Vries and C. J. Elsevier, Handbook of Homogeneous Hydrogenation, Wiley-VCH, Weinheim, Germany, 2007; (c) P. N. Rylander, Catalytic Hydrogenation in Organic Synthesis, Acadamic Press, New York, 1979.

3 Selected reviews: (a) Z.-P. Chen and Y.-G. Zhou, Synthesis, 2016, 48, 1769; (b) B. Balakrishna, J. L. Nùnez-Rico and A. Vidal-Ferran, Eur. J. Org. Chem., 2015, 5293; (c) D.-S. Wang, Q.-A. Chen, S.-M. Lu and Y.-G. Zhou, Chem. Rev., 2012, 112, 2557; (d) Z. Yu, W. Jin and Q. Jiang, Angew. Chem., Int. Ed., 2012, 51, 6060; (e) F. Glorius, Org. Biomol. Chem., 2005, 3, 4171Account: $f(f)$ Y.-E. Luo, Y.-M. He and Q.-H. Fan, Chem. Rec., 2016, 16, 2697; (g) Y.-G. Zhou, Acc. Chem. Res., 2007, 40, 1357.
4 Selected reports on noble metal homogeneous catalysts for N-heteroarene hydrogenation: (a) Á. Vivancos, M. Beller and M. Albrecht, ACS Catal., 2018, 8, 17; (b) C. Schlepphorst, M. Wiesenfeldt and F. Glorius, Chem.-Eur. J., 2018, 24, 354; (c) Z. Yang, F. Chen, S. Zhang, Y. He, N. Yang and Q.-H. Fan, Org. Lett., 2017, 19, 1458; (d) R. Kuwano, Y. Hashiguchi, R. Ikeda and K. Ishizuka, Angew. Chem., Int. Ed., 2015, 54, 2393; (e) T. Wang, L.-G. Zhuo, Z. Li, F. Chen, Z. Ding, Y. He, Q.-H. Fan, J. Xiang, Z.-X. Yu and A. S. C. Chan, J. Am. Chem. Soc., 2011, 133, 9878; (f) G. E. Dobereiner, A. Nova, N. D. Schley, N. Hazari, S. J. Miller, O. Eisenstein and R. H. Crabtree, J. Am. Chem. Soc., 2011, 133, 7547; (g) S. Urban, N. Ortega and F. Glorius, Angew. Chem., Int. Ed., 2011, 50, 3803.

5 Selected reports on noble metal heterogeneous catalysts for N-heteroarene hydrogenation: (a) S. Zhang, Z. Xia, T. Ni, Z. Zhang, Y. Ma and Y. Qu, J. Catal., 2018, 359, 101; (b) X. Wang, W. Chen, L. Zhang, T. Yao, W. Liu, Y. Lin, H. Ju, J. Dong, L. Zheng, W. Yan, X. Zheng, Z. Li, X. Wang, J. Yang, D. He, Y. Wang, Z. Deng, Y. Wu and Y. Li, J. Am. Chem. Soc., 2017, 139, 9419; (c) T.-N. Ye, J. Li, M. Kitano and H. Hosono, Green Chem., 2017, 19, 749; (d) Y.-G. Ji, K. Wei, T. Liu, L. Wu and W.-H. Zhang, Adv. Synth. Catal., 2017, 359, 933; (e) A. Karakulina, A. Gopakumar, İ. Akçok, B. L. Roulier, T. LaGrange, S. A. Katsyuba, S. Das and P. J. Dyson, Angew. Chem., Int. Ed., 2016, 55, 292; $(f)$ Y. Zhang, J. Zhu, Y.-T. Xia, X.-T. Sun and L. Wu, Adv. Synth. Catal., 2016, 358, 3039; (g) M. Niu, Y. Wang, P. Chen, D. Du, J. Jiang and Z. Jin, Catal. Sci. Technol., 2015, 5, 4746; (h) M. Fang and R. A. Sánchez-Delgado, J. Catal., 2014, 311, 357; (i) D. Ren, L. He, L. Yu, R.-S. Ding, Y.-M. Liu, Y. Cao, H.-Y. He and K.-N. Fan, J. Am. Chem. Soc., 2012, 134, 17592; (j) N. A. Beckers, S. Huynh, X. Zhang, E. J. Luber and J. M. Buriak, ACS Catal., 2012, 2, 1524.

6 Reports on non-noble metal homogeneous catalysts for $\mathrm{N}$ heteroarene hydrogenation: (a) R. Adam, J. R. CabreroAntonino, A. Spannenberg, K. Junge, R. Jackstell and M. Beller, Angew. Chem., Int. Ed., 2017, 56, 3216; (b) R. Xu, S. Chakraborty, H. Yuan and W. D. Jones, ACS Catal., 2015, 5, 6350; (c) S. Chakraborty, W. W. Brennessel and W. D. Jones, J. Am. Chem. Soc., 2014, 136, 8564.

7 Reports on non-noble metal heterogeneous catalysts for $\mathrm{N}$ heteroarene hydrogenation: (a) I. Sorribes, L. Liu, A. Doménech-Carbó and A. Corma, ACS Catal., 2018, 8, 4545; (b) J. Li, G. Liu, X. Long, G. Gao, J. Wu and F. Li, J. Catal., 2017, 355, 53; (c) Z. Wei, Y. Chen, J. Wang, D. Su, M. Tang, S. Mao and Y. Wang, ACS Catal., 2016, 6, 5816; (d) F. Chen, A.-E. Surkus, L. He, M.-M. Pohl, J. Radnik, C. Topf, K. Junge and M. Beller, J. Am. Chem. Soc., 2015, 137, 11718; (e) C. Liu, Z. Rong, Z. Sun, Y. Wang, W. Du, Y. Wang and L. Lu, RSC Adv., 2013, 3, 23984.

8 (a) V. Sridharan, P. A. Suryavanshi and J. C. Menéndez, Chem. Rev., 2011, 111, 7157; (b) K. W. Bentley, Nat. Prod. Rep., 2006, 23, 444; (c) A. R. Katritzky, S. Rachwal and B. Rachwal, Tetrahedron, 1996, 52, 15031selected examples:(d) P. J. Houghton, T. Z. Woldemariam, Y. Watanabe and M. Yates, Planta Med., 1999, 65, 250; (e) A. O'Byrne and 
P. Evans, Tetrahedron, 2008, 64, 8067; (f) J. Bálint, G. Egri, E. Fogassy, Z. Böcskei, K. Simon, A. Gajáry and A. Friesz, Tetrahedron: Asymmetry, 1999, 10, 1079; (g) J.-P. Liou, Z.-Y. Wu, C.-C. Kuo, C.-Y. Chang, P.-Y. Lu, C.-M. Chen, H.-P. Hsieh and J.-Y. Chang, J. Med. Chem., 2008, 51, 4351; (h) C. D. Jesudason, L. S. Beavers, J. Cramer, J. Dill, D. R. Finley, C. W. Lindsley, F. C. Stevens, R. A. Gadski, S. W. Oldham, R. T. Pickard, C. S. Siedem, D. K. Sindelar, A. Singh, B. M. Watson and P. A. Hipskind, Bioorg. Med. Chem. Lett., 2006, 16, 3415.

9 R. Chen, X. Yang, H. Tian, X. Wang, A. Hagfeldt and L. Sun, Chem. Mater., 2007, 19, 4007.

10 Selected reviews: (a) G. A. Filonenko, R. van Putten, E. J. M. Hensen and E. A. Pidko, Chem. Soc. Rev., 2018, 47, 1459; (b) F. Kallmeier and R. Kempe, Angew. Chem., Int. Ed., 2018, 57, 46selected accounts:(c) P. J. Chirik, Acc. Chem. Res., 2015, 48, 1687; (d) R. H. Morris, Acc. Chem. Res., 2015, 48, 1494; (e) T. Zell and D. Milstein, Acc. Chem. Res., 2015, 48, 1979; (f) S. Chakraborty, P. Bhattacharya, H. Dai and H. Guan, Acc. Chem. Res., 2015, 48, 1995perspective: $(g)$ R. M. Bullock, Science, 2013, 342, 1054.

11 (a) A. Fürstner, ACS Cent. Sci., 2016, 2, 778; (b) O. R. Luca and R. H. Crabtree, Chem. Soc. Rev., 2013, 42, 1440; (c) P. J. Chirik and K. Wieghardt, Science, 2010, 327, 794.

12 J. E. Shaw and P. R. Stapp, J. Heterocycl. Chem., 1987, 24, 1477.

13 Selected reviews: (a) L. Liu and A. Corma, Chem. Rev., 2018, 118, 4981; (b) Z. Ye, P. Zhang, X. Lei, X. Wang, N. Zhao and H. Yang, Chem.-Eur. J., 2018, 24, 8922; (c) D. Wang and D. Astruc, Chem. Soc. Rev., 2017, 46, 816; (d) Y. Cao, S. Mao, M. Li, Y. Chen and Y. Wang, ACS Catal., 2017, 7, 8090; (e) L. He, F. Weniger, H. Neumann and M. Beller, Angew. Chem., Int. Ed., 2016, 55, 12582; $(f)$ M. Li, F. Xu, H. Li and Y. Wang, Catal. Sci. Technol., 2016, 6, 3670; $(g)$ E. Pérez-Mayoral, V. Calvino-Casilda and E. Soriano, Catal. Sci. Technol., 2016, 6, 1265.

14 Selected reports: (a) W. Liu, L. Zhang, X. Liu, X. Liu, X. Yang, S. Miao, W. Wang, A. Wang and T. Zhang, J. Am. Chem. Soc., 2017, 139, 10790; (b) P. Zhou, L. Jiang, F. Wang, K. Deng, K. Lv and Z. Zhang, Sci. Adv., 2017, 3, e1601945; (c) J. Xie, K. Yin, A. Serov, K. Artyushkova, H. N. Pham, X. Sang, R. R. Unocic, P. Atanassov, A. K. Datye and R. J. Davis, ChemSusChem, 2017, 10, 359; (d) F. Chen, B. Sahoo, C. Kreyenschulte, H. Lund, M. Zeng, L. He, K. Junge and M. Beller, Chem. Sci., 2017, 8, 6239; (e) J. Shi, Y. Wang, W. Du and Z. Hou, Carbon, 2016, 99, 330; (f) W. Zhong, H. Liu, C. Bai, S. Liao and Y. Li, ACS Catal., 2015, 5, 1850; (g) L. Zhang, A. Wang, W. Wang, Y. Huang, X. Liu, S. Miao, J. Liu and T. Zhang, ACS Catal., 2015, 5, 6563.

$15(a) \quad$ R. Ferraccioli, D. Borovika, A.-E. Surkus, C. Kreyenschulte, C. Topf and M. Beller, Catal. Sci. Technol., 2018, 8, 499; (b) R. V. Jagadeesh, K. Murugesan, A. S. Alshammari, H. Neumann, M.-M. Pohl, J. Radnik and M. Beller, Science, 2017, 358, 326; (c) B. Sahoo, A.-E. Surkus, M.-M. Pohl, J. Radnik, M. Schneider, S. Bachmann, M. Scalone, K. Junge and M. Beller, Angew.
Chem., Int. Ed., 2017, 56, 11242; (d) D. Formenti, F. Ferretti, C. Topf, A.-E. Surkus, M.-M. Pohl, J. Radnik, M. Schneider, K. Junge, M. Beller and F. Ragaini, J. Catal., 2017, 351, 79; (e) F. Chen, C. Kreyenschulte, J. Radnik, H. Lund, A.-E. Surkus, K. Junge and M. Beller, ACS Catal., 2017, 7, 1526; (f) F. Chen, C. Topf, J. Radnik, C. Kreyenschulte, H. Lund, M. Schneider, A.-E. Surkus, L. He, K. Junge and M. Beller, J. Am. Chem. Soc., 2016, 138, 8781; $(g)$ R. V. Jagadeesh, H. Junge, M.-M. Pohl, J. Radnik, A. Brückner and M. Beller, J. Am. Chem. Soc., 2013, 135, 10776; (h) R. V. Jagadeesh, A.-E. Surkus, H. Junge, M.-M. Pohl, J. Radnik, J. Rabeah, H. M. Huan, V. Schunemann, A. Brückner and M. Beller, Science, 2013, 342, 1073; (i) F. A. Westerhaus, R. V. Jagadeesh, G. Wienhöfer, M.-M. Pohl, J. Radnik, A.-E. Surkus, J. Rabeah, K. Junge, H. Junge, M. Nielsen, A. Brückner and M. Beller, Nat. Chem., 2013, 5, 537.

16 (a) Y. Sun, L. Chen, Y. Bao, G. Wang, Y. Zhang, M. Fu, J. Wu and D. Ye, Catal. Today, 2018, 307, 212; (b) R. Shi, J. Zhao, S. Liu, W. Sun, H. Li, P. Hao, Z. Li and J. Ren, Carbon, 2018, 130, 185; (c) C. E. Chan-Thaw, A. Villa, G. M. Veith and L. Prati, ChemCatChem, 2015, 7, 1338.

17 (a) W. Meng, B. Breiner, K. Rissanen, J. D. Thoburn, J. K. Clegg and J. R. Nitschke, Angew. Chem., Int. Ed., 2011, 50, 3479; (b) D. Wilson, B. Djukic and M. T. Lemaire, Transition Met. Chem., 2014, 39, 17.

18 See ESI. $\dagger$

19 C. Tang, A.-E. Surkus, F. Chen, M.-M. Pohl, G. Agostini, M. Schneider, H. Junge and M. Beller, Angew. Chem., Int. Ed., 2017, 56, 16616.

20 F. Bonnet, F. Ropital, P. Lecour, D. Espinat, Y. Huiban, L. Gengembre, Y. Berthier and P. Marcus, Surf. Interface Anal., 2002, 34, 418.

21 F. Jaouen, J. Herranz, M. Lefèvre, J.-P. Dodelet, U. I. Kramm, I. Herrmann, P. Bogdanoff, J. Maruyama, T. Nagaoka, A. Garsuch, J. R. Dahn, T. Olson, S. Pylypenko, P. Atanassov and E. A. Ustinov, ACS Appl. Mater. Interfaces, 2009, 1, 1623.

22 (a) X. Xin, H. Qin, H.-P. Cong and S.-H. Yu, Langmuir, 2018, 34, 4952; (b) R. Cao, R. Thapa, H. Kim, X. Xu, M. G. Kim, Q. Li, N. Park, M. Liu and J. Cho, Nat. Commun., 2013, 4, 2076; (c) Y. Zhao, K. Watanabe and K. Hashimoto, J. Am. Chem. Soc., 2012, 134, 19528.

23 Y. S. Ponosov, M. A. Uimin, A. E. Ermakov, N. N. Shchegoleva and A. A. Mysik, Phys. Solid State, 2013, 55, 1528.

24 R. J. Pagliero, S. Lusvarghi, A. B. Pierini, R. Brun and M. R. Mazzieri, Bioorg. Med. Chem., 2010, 18, 142.

25 L. R. Bush, Cardiovasc. Drug Rev., 1991, 9, 247.

26 G. E. Hardtmann, US Pat., 4015005, 1977.

27 M. C. Maillard, M. E. Perlman, O. Amitay, D. Baxter, D. Berlove, S. Connaughton, J. B. Fischer, J. Q. Guo, L.-Y. Hu, R. N. McBurney, P. I. Nagy, K. Subbarao, E. A. Yost, L. Zhang and G. Durant, J. Med. Chem., 1998, 41, 3048.

28 P. Kathirgamanathan and S. Surendrakumar, US Pat., 112854, 2009. 